\title{
AN UPDATED SPECIES LIST OF MEDIUM AND LARGE-SIZED MAMMALS OF THE AUGUSTO RUSCHI BIOLOGICAL RESERVE, USING A NOVEL SAMPLING DESIGN
}

\author{
Jade Huguenin ${ }^{1}$, Juliana Rodrigues Ferreira ${ }^{1}$, Danielle Oliveira Moreira ${ }^{1}$, Andressa Gatti ${ }^{1}$, \\ Sérgio Lucena Mendes ${ }^{1,2}$ \& Marina Zanin ${ }^{1,3^{*}}$
}

\footnotetext{
${ }^{1}$ Universidade Federal do Espírito Santo, Centro de Ciências Humanas e Naturais, Departamento de Ciências Biológicas, Av. Fernando Ferrari, 514, Goiabeiras, CEP 29075-910, Vitória, ES, Brazil.

${ }^{2}$ Instituto Nacional da Mata Atlântica, Av. José Ruschi, n. 4, Centro, CEP 29650-000, Santa Teresa, ES, Brazil.

${ }^{3}$ Universidade Federal do Maranhão, Departamento de Ciências Biológicas, Programa de Pós-Graduação em Biodiversidade e Conservação, Av. dos Portugueses, 1966, Vila Bacanga, CEP 65080-805, São Luís, MA, Brazil.

E-mails: hugueninjade@gmail.com; ju.rf.mb@hotmail.com; daniomoreira@gmail.com; gatti.andressa@gmail.com; slmendes1@gmail.com; marinazaning@gmail.com (*corresponding author)
}

\begin{abstract}
Monitoring biological communities through time helps reveal the state of habitat conservation. We performed a new inventory of the medium and large-sized mammals in the Augusto Ruschi Biological Reserve, southeastern Brazil. Our assessment was based on a new camera-trapping sampling design that incorporates a one-year Enhanced Vegetation Index (EVI) to characterize environmental heterogeneity across the study area. We selected sampling locations in different microhabitats to conduct a 90-day camera trap monitoring. Our sampling effort was 28,704 hours, resulting in 755 photographic records, from which we identified 15 native medium and large-sized mammals, one small-sized mammal (Guerlinguetus brasiliensis), and one exotic species (Canis familiaris). The native mammals included four species not listed in the last inventory carried out in the study area: Dasypus novemcinctus (nine-banded armadillo), Tamandua tetradactyla (collared anteater), Herpailurus yagouaroundi (jaguarundi), and Cerdocyon thous (crab-eating fox). This outcome may indicate the efficiency of our sampling design, which represents an innovative approach to characterizing local mammal communities across an environmental gradient, ensuring broad representation of different resources and habitat characteristics. Consequently, our approach may ensure the recording of the local mammal assemblage and is an appropriate option for inventorying and monitoring medium to large-sized mammals.
\end{abstract}

Keywords: camera-trapping; Mammalia; protected area; survey; wildlife conservation.

\section{INTRODUCTION}

The Atlantic Forest is one of the richest Neotropical biomes, but it is also the most threatened due to extensive habitat destruction (Myers et al. 2000, Pimm \& Jenkins 2010). Such threats make it crucial to study biodiversity continuously across habitats and through time, particularly in localities pointed out as priorityareas for conservation due to theirbiodiversity value. Continuous or periodic monitoring enables assessments of the status of species conservation, evaluation of threats, and the design of management 
strategies to avoid or mitigate such threats (Ervin 2003, Rao et al. 2007). Although many inventories of Atlantic Forest biodiversity have been carried out recently (e.g., Gatti et al. 2017, Oliveira et al. 2017), knowledge gaps remain for all groups of flora and fauna, including mammals (Oliveira et al. 2017).

Fortunately, efforts are being made to fill these knowledge gaps. In the Brazilian Espírito Santo State, updates to the mammal species list have been published in the last 10 years. For example, Moreira et al. (2008) conducted a detailed assessment of the mammalian fauna of Espírito Santo state. For the central mountain region of this state in the Santa Teresa municipality, a field report (Srbek-Araujo \& Chiarello 2007), a museum compilation (Passamani et al. 2000), and a literature review (Moreira et al. 2008) have been presented on its medium and largesized mammals. Moreover, an assessment of the mammalian fauna was conducted in 2008 in the Augusto Ruschi Biological Reserve (ARBR hereafter), representing the most recent mammal species list for the region (Gatti et al. 2014).

The concentration of inventories conducted in the central mountain region of Espírito Santo State is justified due to its relevance to the conservation of the Atlantic Forest mammal biodiversity, as demonstrated by Galetti et al. (2009). These authors evaluated priority areas for conservation according to their species richness representativeness, population abundances, body sizes of different species, conservation status, and forest patch areas (Galetti et al. 2009). Therefore, we carried out a new inventory of the medium and large-sized mammals in the ARBR based on a new sampling design that accounts for environmental factors acting on the spatial organization of mammals. We sorted our sampling units according to an environmental gradient, represented by the Enhanced Vegetation Index. We compare our results with those of previous species inventories and confirm the occurrence or absence of some mammal species after an eight-year monitoring gap.

\section{MATERIAL AND METHODS}

\section{Study area}

The study was conducted in the ARBR, located in the municipality of Santa Teresa, Espírito Santo State, Brazil (1954'20”S, 40³3'44”W, datum WGS84) (Figure 1A). The ARBR is a strictly protected area (equivalent to International Union for the Conservation of Nature IUCN category Ia), in which only indirect use of natural resources is permitted (Brasil 2000). The reserve covers an area of 3,598.41 ha, comprising Dense Ombrophylous Forest vegetation, steep slopes, and small floodplains and outcrops (Gonçalves 1997). The altitude varies between 780 and 1,050 $\mathrm{m}$ (Gonçalves 1997).

\section{Sampling design and habitat characterization}

We installed camera traps at 14 sampling stations, which we purposefully selected in the field to maximize environmental heterogeneity (assessed according to the protocol described below) and accounting for logistical feasibility. One of the 14 camera traps was stolen during sampling, and the remaining 13 sampling stations ranged between one and eight kilometer of distance. Camera traps were fixed to trees at a height of $30-40 \mathrm{~cm}$ from the ground. We used bait (scent lures) to attract carnivores (Calvin Klein ${ }^{\circledR}$ Obsession for Men) (Cove et al. 2014). The equipment was active continuously during four months, between September and December 2016.

We assessed one-year Enhanced Vegetation Index (EVI) data over the entire ARBR, using a $4 \mathrm{~km}^{2}$ grid cell resolution to environmentally characterize the sampling area and to measure heterogeneity among localities. We downloaded EVI data through the "MODISTools" package (Tuck et al. 2014) in the R software (R Core Team 2016). EVI consists of reflectance information on biomass density with low atmospheric interference obtained by the MODIS sensor at 16-day intervals (Huete et al. 2002). We synthesized the global information for each grid cell through basic and circular statistics to describe each cell's central tendency and variation. This process generated a set of variables representing environmental heterogeneity, assessed according to the following EVI statistics: integral average, standard deviation of the integral data, coefficient of variation of the integral data, average of the highest quartile, lowest annual value, average of the lowest quartile, highest annual value, amplitude, and circular average of most productive station. Basic statistics were calculated using the "stats" package (R Core Team 2016), and the "CircStats" package (Lund \& Agostinelli 2012) was used for circular statistics, both of which were implemented in R (R Core Team 2016).

We conducted a Principal Component Analysis (PCA) to reduce the dimensionality of the EVI index 

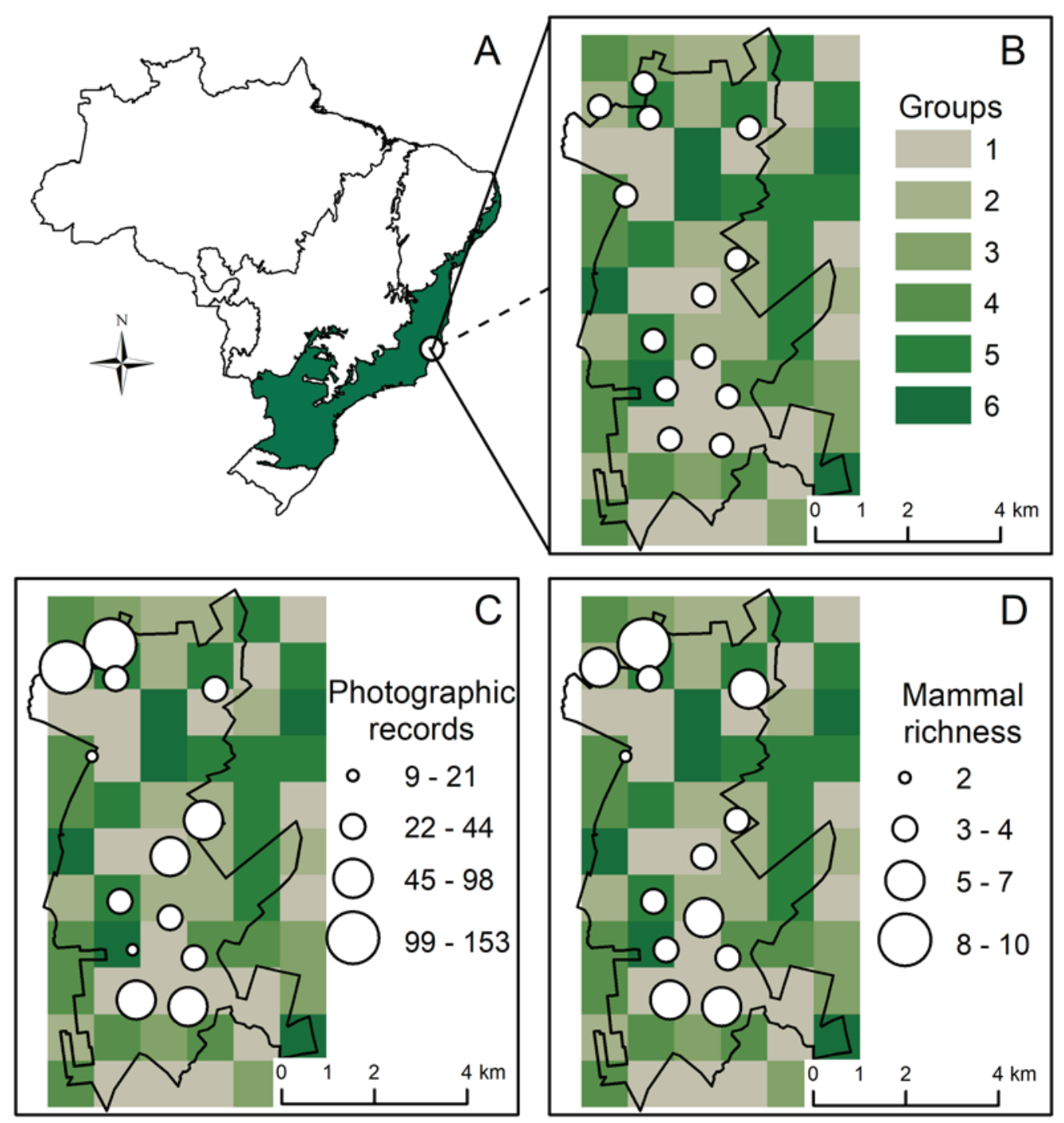

Figure 1. Location of the Augusto Ruschi Biological Reserve, Espírito Santo State, Brazil (A). Sampling stations of the camera traps used for the mammal inventory between September and December 2016 (white points) located in six groups of environmental characteristics representing a gradient based on the Enhanced Vegetation Index (B). Categorization of the sampling stations according to the number of photographic records $(\mathrm{C})$, and according to mammal richness $(\mathrm{D})$.

variables (Legendre \& Legendre 1998), which we performed using the "ade4" package (Dray \& Dufour 2007) in R (R Core Team 2016). Grid cells were divided into six groups of ecological similarity based on our principal component scores. The grouping was performed using K-means analysis, which consists of a divisible and non-hierarchical cluster analysis (Legendre \& Legendre 1998). Our objective was to select two sampling stations (grid cells) for each of the six ecological groups, so we defined $\mathrm{K}=$ 6. This analysis was conducted in R using the "stats" package (R Core Team 2016).

\section{Photographic data identification and analysis}

Recorded species were identified to the lowest taxonomic level possible, mainly following the nomenclature proposed by Wilson \& Reeder (2005). For rodents, we consulted Patton et al. (2015). We followed Chiarello (2000) in considering mammals with a body weight $>1 \mathrm{~kg}$ but $<20 \mathrm{~kg}$ as medium-sized, and Carbone et al. (1999) in defining mammals $>20 \mathrm{~kg}$ as large. To assess individual species' threat status, we consulted the IUCN red list (IUCN 2018) and the Brazilian red book (ICMBio 2016). Camera trap sampling effort was determined by the total sampling hours and sampling adequacy was estimated using a species accumulation curve following Colwell et al. (2012). We also assessed species richness for each sampled grid cell.

We evaluated the ability of our sampling 
design to describe differential mammal species occurrence by calculating an average dissimilarity index for each sampling unit. The dissimilarity index used was derived from the Bray-Curtis index for binary data (Bray \& Curtis 1957). We choose to represent the mammal assemblage through discrete presence and absence data because the objective of mammal assessment is to provide a list of species occurrence. We expected to record equivalent average dissimilarity across sampling units, suggesting complementarity among sampling units and similar contributions to our description of the study area assemblage.

\section{RESULTS}

The PCA generated two orthogonal axes that represented $56 \%$ and $34 \%$ of the environmental variability, respectively. After the second axis, there is an abrupt drop in the explained proportion of variation (Figure 2A). The first principal component correlates strongly with the circular average of the most productive station, whereas the second principal component is best represented by the integral average of EVI (Figure 2B). Mapping the heterogeneity captured by both PCA axes using the six K-means groups, we observed that selected sampling stations were satisfactorily distributed across the environmental gradient of the study area (Figure 1B). Each of the six groups represents a different category of environmental variation: 1 -low values for both axes; 2 - low values for the first axis and high values for the second axis; 3 - high positive values for the first axis and low to intermediate negative values for the second axis; 4 - positive values for the first axis and high negative values for the second axis; 5 - intermediate to high positive values for the first axis; and 6 - high positive values for the first axis and low to intermediate values for the second axis (Figure 2C).

Our camera-trapping sampling effort amounted to 28,704 hours, which resulted in 755 photographic records of identifiable mammals. The number of species records was not evenly distributed throughout the ARBR (Figure 1C). We identified 15 native medium and large-sized mammals, one smallsized mammal (Guerlinguetus brasiliensis), and one exotic species (Canis familiaris), representing a total of 17 mammal species from eight orders and 13 families (Table 1; Figure 3 and 4). We could only identify to genus level some photographic records for brocket deer of the genus Mazama, small spotted felids of the genus Leopardus, and armadillos of the genus Dasypus. The species accumulation curve reached sampling sufficiency at 13 sites, as demonstrated by the confidence interval for the thirteenth sampling station (Figure 5).

The richest order was Carnivora $(\mathrm{N}=9)$, followed by Artiodactyla $(\mathrm{N}=2)$. The species with the highest number of records was the domestic dog, followed by Cuniculus paca (spotted paca) and Didelphis aurita (big-eared opossum) (Figure 6A). Didelphis aurita, Nasua nasua (South American coati) and

Table 1. Species list of mammals recorded in the Augusto Ruschi Biological Reserve, Espírito Santo State, Brazil. Conservation status according to the International Union for Conservation of Nature Red List of Threatened Species (2016) and ICMBio-MMA Brazilian Red Book (2016). Status abbreviations: LC = Least Concern, NT = Near Threatened, VU = Vulnerable.

\begin{tabular}{llcc}
\hline Species & Name & IUCN & MMA \\
\hline Order Didelphimorphia & & & \\
Family Didelphidae & & & \\
\multicolumn{1}{c}{ Didelphis aurita Wied-Neuwied, 1826 } & Big-eared opossum & LC & LC \\
Order Pilosa & & & \\
Family Myrmecophagidae & & LC & LC \\
$\quad$ Tamandua tetradactyla Linneaus, 1758 & Collared anteater & & \\
Order Cingulata & & & \\
\hline Family Dasypodidae & & & \\
\hline
\end{tabular}

Table 1. Continued on next page... 
Table 1....Continued

\begin{tabular}{llcc}
\hline Species & Name & IUCN & MMA \\
\hline Dasypus novemcinctus Linneaus, 1758 & Nine-banded armadillo & LC & LC \\
Dasypus sp. & Armadillo & - & - \\
Order Artiodactyla & & &
\end{tabular}

\section{Family Cervidae}

Mazama sp.

\section{Family Tayassuidae}

Pecari tajacu Linneaus, 1758

\section{Order Primates}

Family Cebidae

Sapajus nigritus (Goldfuss, 1809)

Order Carnivora

\section{Family Canidae}

Canis familiaris Linnaeus, 1758

Cerdocyon thous (Linnaeus, 1766)

\section{Family Felidae}

Leopardus guttulus (Hensel, 1872)

Leopardus pardalis (Linneaus, 1758)

Puma concolor (Linneaus, 1771)

Herpailurus yagouaroundi (É. Geoffroy Saint-Hilaire, 1803)

\section{Family Mustelidae}

Eira barbara (Linneaus, 1758)

Tayra

LC

LC

\section{Family Procyonidae}

$$
\text { Nasua nasua Linneaus, } 1766
$$

Procyon cancrivorus (G. [Baron] Cuvier, 1798)

\section{Order Lagomorpha}

\section{Family Leporidae}

\begin{tabular}{llll} 
Sylvilagus brasiliensis (Linneaus, 1758) & Forest rabbit & LC & LC \\
Order Rodentia & & & \\
Family Cuniculidae & & LC & LC \\
\hline Cuniculus paca Linnaeus, 1766 & Spotted paca & L
\end{tabular}

the domestic dog were the species with the broadest distributions (Figure 6B), but none of these was registered by all camera stations (Figure 6B). Mammal richness was not evenly distributed throughout the ARBR (Figure 1D), with camera stations recording from 2 to 10 mammal species. However, the average dissimilarity indexhad lowvariation among sampling units $(0.33 \pm 0.07)$, suggesting that each sampling station contributed similarly to characterize the medium to large mammal assemblage of the ARBR. 

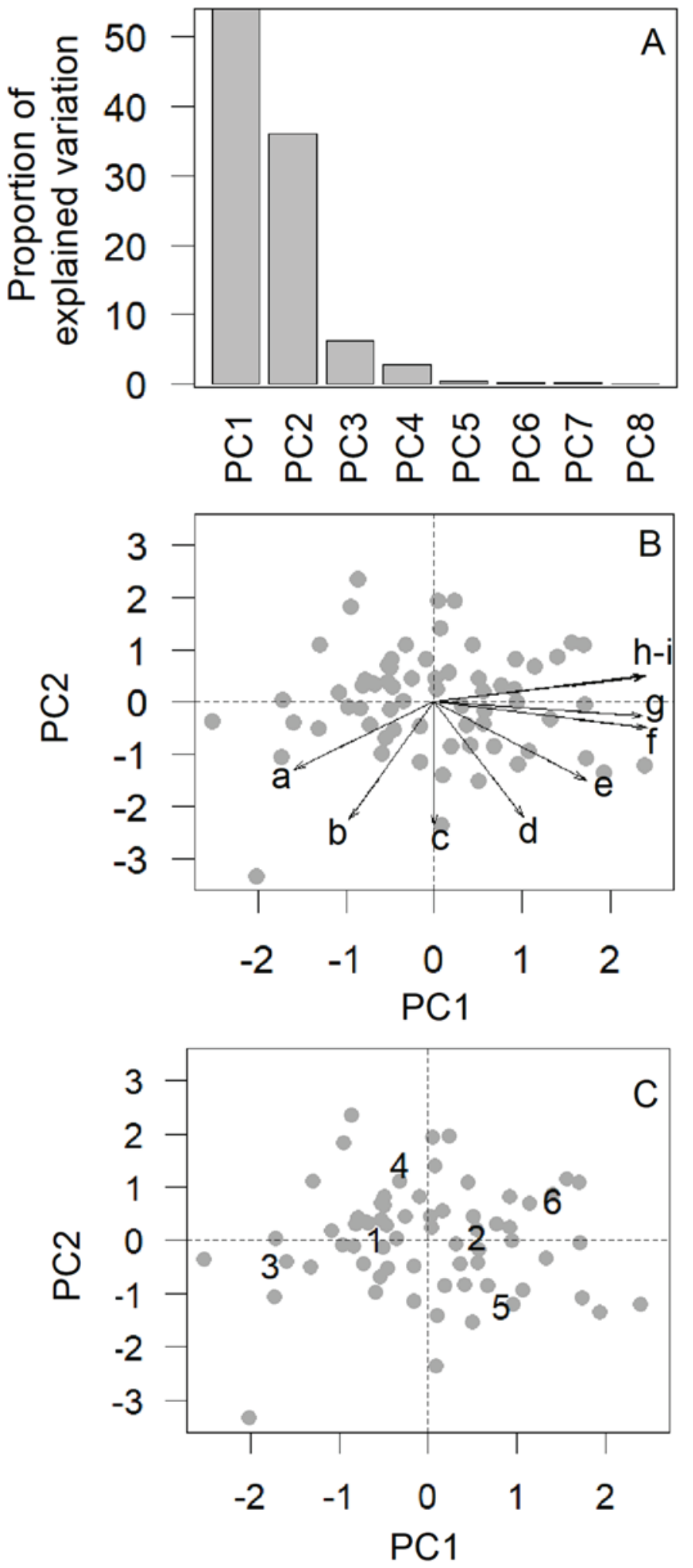

Figure 2. Principal component analysis of the variables of the Enhanced Vegetation Index in the Augusto Ruschi Biological Reserve, Espírito Santo State, Brazil. A. Proportion of variation explained by each principal component. B. Environmental ordination of grid cells (gray points) and correlation of the original variables with the selected axes (vectors) assessed according to the following EVI statistics: a - lowest annual value, $\mathrm{b}$ - average of the lowest quartile, c- integral average, $\mathrm{d}$ - average of the highest quartile, $\mathrm{e}$ - highest annual value, $\mathrm{f}$ - standard deviation, $\mathrm{g}$ - circular average of most productive station, $\mathrm{h}$ - amplitude, and $\mathrm{i}$ - coefficient of variation. C. Ordination of K-means groups: numbers 1 to 6 represent each category of environmental variation. 


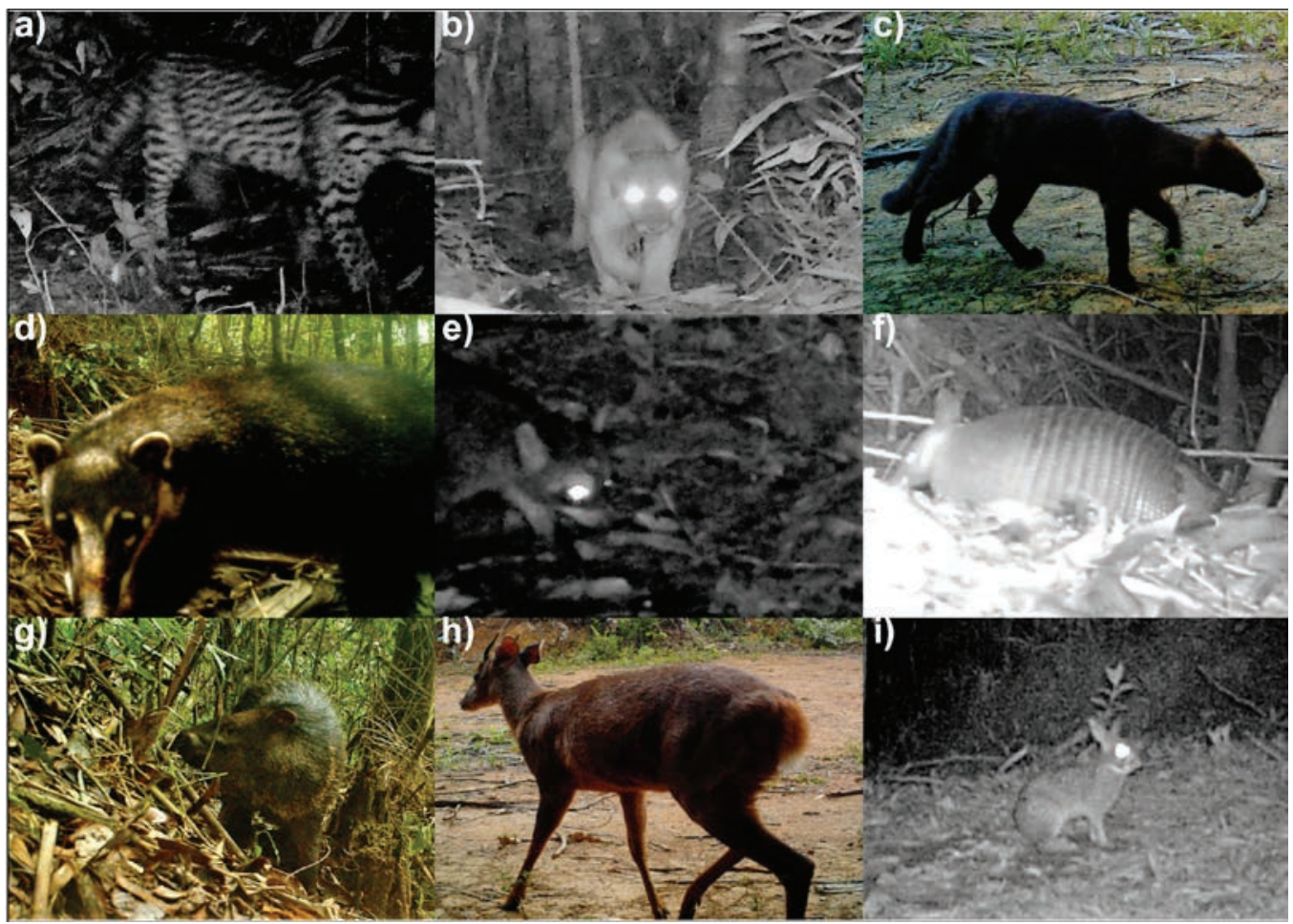

Figure 3. Photographic records of mammal species recorded in the Augusto Ruschi Biological Reserve, Espírito Santo State, Brazil. (a) Leopardus pardalis, (b) Puma concolor, (c) Herpailurus yagouaroundi, (d) Nasua nasua, (e) Procyon cancrivorus, (f) Dasypus novemcinctus, (g) Pecari tajacu, (h) Mazama sp., (i) Sylvilagus brasiliensis

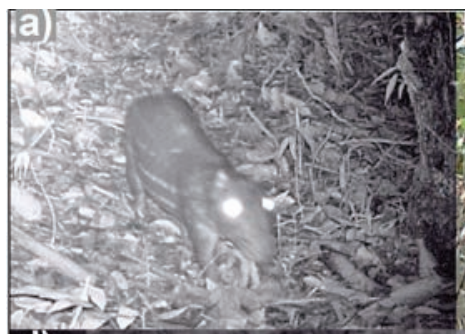

d)
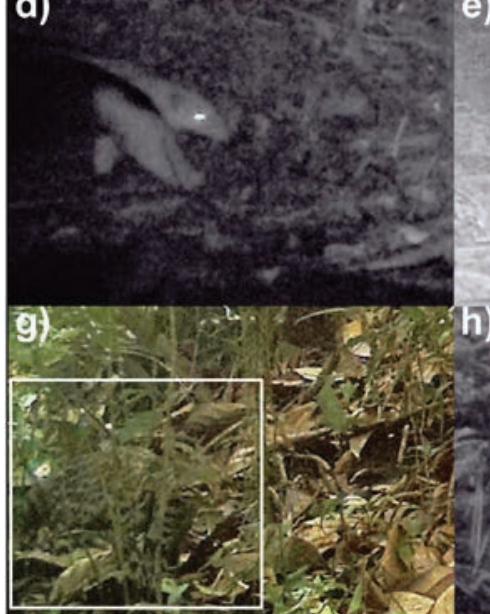

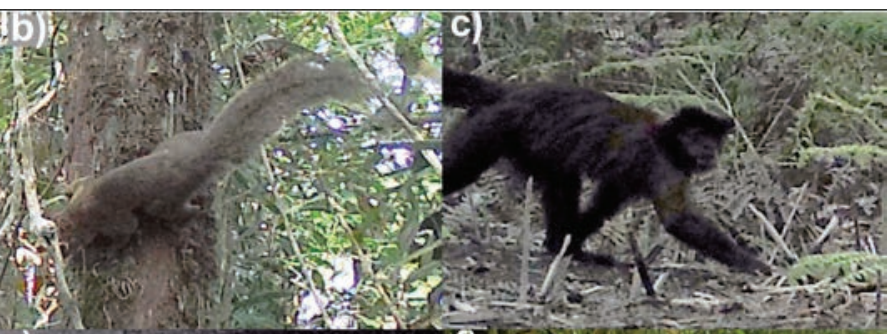

e)

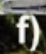

Figure 4. Photographic records of mammal species recorded in the Augusto Ruschi Biological Reserve, Espírito Santo State, Brazil. (a) Cuniculus paca, (b) Guerlinguetus brasiliensis, (c) Sapajus nigritus, (d) Tamandua tetradactyla, (e) Didelphis aurita, (f) Eira barbara, (g) Leopardus guttulus, (h) Cerdocyon thous, and (i) Canis familiaris 


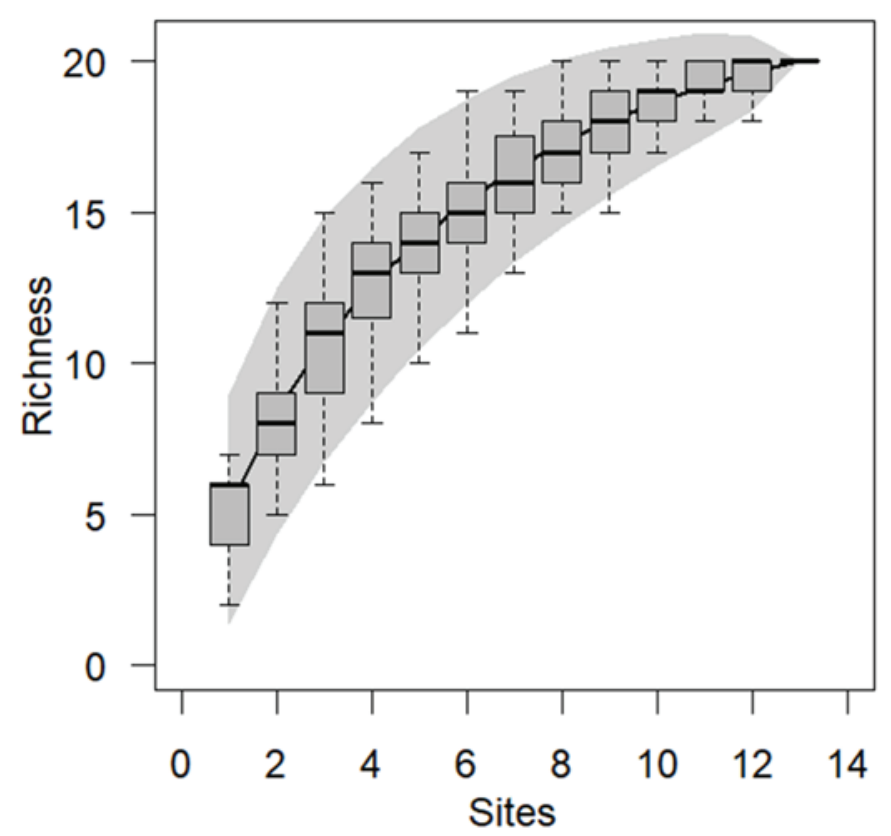

Figure 5. Species accumulation curve relating mammal species richness to number of sampled sites, confirming the sampling efficiency of our camera trapping methodology used in the Augusto Ruschi Biological Reserve, Espírito Santo State, Brazil. Boxplots represent the average and standard deviation richness by sampling units whereas the gray shadow represents the confidence interval measured by 1000 random samples.
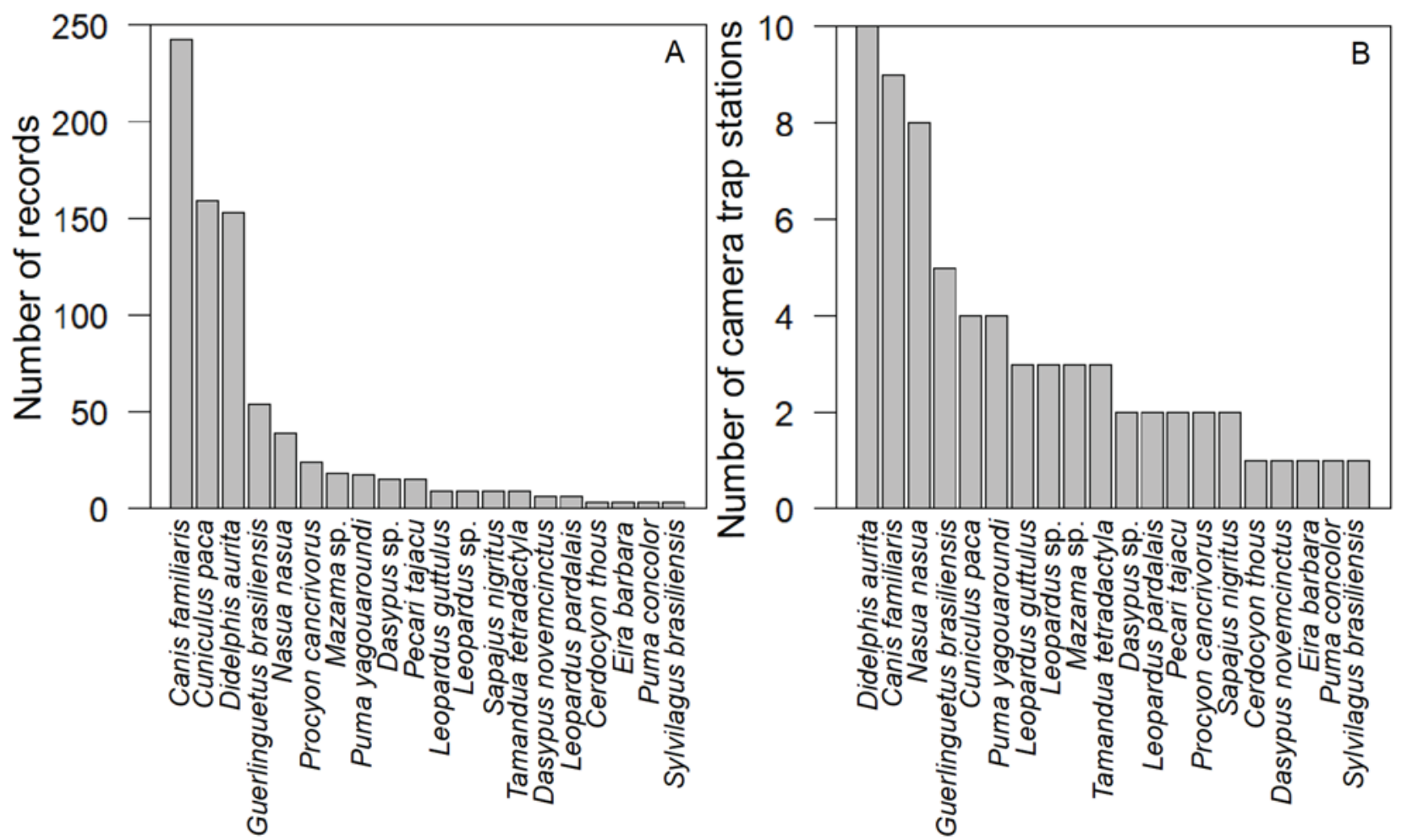

Figure 6. Number of photographic records for each large and medium-sized mammal species (A) and number of camera trap stations where they were recorded (B) in the Augusto Ruschi Biological Reserve, Espírito Santo State, Brazil. 
Regarding threatened status, only the Leopardus guttulus (Southern little spotted cat) is classified as vulnerable according to the IUCN red list. However, considering the Brazilian red book (ICMBio 2016), three species are categorized as threatened, i.e., Herpailurus yagouaroundi, L. guttulus and Puma concolor (Table 1).

\section{DISCUSSION}

This study updates the 2008 mammal inventory for the ARBR (Gatti et al. 2014), for which we found a similar mammal assemblage. Gatti et al. (2014) reported 29 medium and large-sized mammals (including the domestic dog), but only 19 of these were recorded from field-based methods. Lack of arboreal species like Bradypus torquatus (maned sloth) and Brachyteles hypoxanthus (Northern muriqui) is the main difference among the species recorded in our study and those registered using field-based methods by Gatti et al. (2014). Since our camera traps were fixed close to the ground, arboreal species could only be recorded opportunistically, such as our records of Sapajus robustus (black capuchin). However, we confirmed the occurrence of four species that were not reported by Gatti et al. (2014): the Dasypus novemcinctus (nine-banded armadillo), the Tamandua tetradactyla (collared anteater), the H. yagouaroundi (jaguarundi), and the Cerdocyon thous (crab-eating fox). Moreover, other mammal inventories conducted in Espírito Santo State have registered approximately the same mammal species richness as our study (17-20 species), taking account of differences in sampling methods (e.g., transects or censuses, trapping, spoor, and surveying museum collections), which differed among studies (Passamani et al. 2000, Tonini et al. 2010, Delciellos et al. 2012, Ferreguetti et al.2014, Gatti et al.2014, Gatti et al.2017, Guerra \& Leite 2017).

Therefore, we assert that our approach is effective for sampling medium and large terrestrial mammals considering a small number of sampling stations. We highlight two main reasons contributing to the effectiveness of this approach. The first is logistical feasibility of the camera trap method and its efficiency for monitoring terrestrial vertebrates, especially solitary species and those exhibiting secretive behaviors (Bridges \& Noss
2011). The second is our sampling design, which is an innovative approach for mammal inventories and proved to be appropriate for characterizing the local mammal community across different microhabitats. This methodological approach ensures the broadest representation of microhabitat characteristics and potential resource usage across the study area, which efficiently increases the diversity of species recorded (Magurran 1988). The EVI permits broad environmental representation across different spatial and temporal scales, enabling multi-scale analyses (Fernández 2013, Palomares et al. 2016). Therefore, it has advantages over local representations of phytophysionomies or vegetation formations, which have more homogeneous spatial and temporal patterns (Fernández 2013, Palomares et al. 2016).

The native medium and large-sized mammals recorded in this study $(\mathrm{N}=15)$ represent $21.42 \%$ of such species known to occur in the Atlantic Forest (according to Paglia et al.2012) and $36.58 \%$ of those reported in Espírito Santo State (Moreira et al. 2008). When we compared our results to those of 10 and 18 years ago for the municipality of Santa Teresa (i.e., Passamani et al. 2000, Srbek-Araujo \& Chiarello 2007, Gatti et al. 2014), most of the species listed in those previous studies are still present in the ARBR. This scenario reinforces the importance of the ARBR to the regional conservation of mammals. However, maintaining species richness does not necessarily reflect population stability for a species, which is evidenced by the degree of local extinction of large-sized mammals, such as the Panthera onca (jaguar), the Tayassu pecari (white-lipped peccary), and most recently the Tapirus terrestris (lowland tapir) (Chiarello et al. 2007, Flesher \& Gatti 2010). Instead, estimates of population density are required to assess the longterm conservation status of focal species (Ehrlén \& Morris 2015).

Our study highlights the ubiquitous presence of the domestic dog as an invasive species, which likely has a highly negative impact on the biodiversity of the ARBR. This threat has persisted over the years in this region and represents a major problem for wildlife conservation, especially in protected areas (Srbek-Araujo \& Chiarello 2008, Lacerda et al. 2009, Gatti et al. 2014, Lessa et al. 2016). Other potential anthropogenic threats are also present in the study area, such as agricultural encroachment (primarily 
coffee; Pinto et al. 1993), Eucalyptus plantations, and hunting pressure (Mendes \& Padovan 2000), which may mutually reinforce the negative effects on the reserve's populations of medium and largesized mammals.

All these threats are relevant to the conservation of mammal species and their populations since the central mountainous region of Espírito Santo State still harbors emblematic species, such as the $P$. concolor (puma), the critically threatened B. hypoxanthus (Northern muriqui), and the vulnerable $B$. torquatus (maned sloth) (see Passamani et al. 2000, Moreira et al. 2008, Gatti et al. 2014). The presence of these species suggests the landscape retains some of its habitat integrity and therefore still possesses conservation potential (Galetti et al. 2009). Consequently, mitigation of the many anthropogenic impacts and continuous biodiversity monitoring should be a management priority to ensure the survival of mammal populations in the region, reinforcing the importance of an effective sampling design to increase the feasibility of long-term monitoring and to ensure species representability, as achieved by the methodology applied in this study.

\section{ACKNOWLEDGEMENTS}

We thank Evanildo José Volpi and Rogério Ribeiro for help with fieldwork. This study was authorized by the Brazilian environmental authority (Instituto Chico Mendes de Conservação da Biodiversidade - ICMBio; Number: 54003-1) and it was supported by the Research Support Foundation of the state of Espírito Santo (Fundação de Amparo à Pesquisa do Espírito Santo) through project number 0833/2015. $\mathrm{MZ}$ is supported by a CNPq DCR fellowship (number 312627/2015-7). DOM is supported by a Capes PNPD fellowship.

\section{REFERENCES}

Brasil. 2000. Lei no 9985 de 18 de julho de 2000. "Regulamenta o art. 225, § 1o, incisos I, II, III e VII da Constituição Federal, institui o Sistema Nacional de Unidades de Conservação da Natureza e dá outras providências". Available in http://www.planalto.gov.br/ccivil_03/leis/ L9985.htm.
Bray, J. R, \& Curtis, J. T. 1957. An ordination of the upland forest communities of Southern Wisconsin. Ecological Monographs, 27 (4), 325349. DOI: $10.2307 / 1942268$.

Bridges, A. S., \& Noss, A. J. 2011. Behavior and activity patterns. In: A. F. O'Connell, J. D. Nichols, \& K. U. Karanth (Eds.), Camera Traps in Animal Ecology: Methods and Analyses. pp. 57-70. New York: Springer.

Carbone, C. G., Mace, G., Roberts, S. C., \& MacDonald, D. W. 1999. Energetic constraints on the diet of terrestrial carnivores. Nature, 402, 286-288. DOI: 10.1038/46266.

Chiarello, A. G. 2000. Density and population size of mammals in remnants of Brazilian Atlantic Forest. Conservation Biology, 14(6),1649-1657. DOI: $10.1111 /$ j.1523-1739.2000.99071.x.

Chiarello, A. G., Costa, L. P., Leite, Y. L. R., Passamani, M., Siciliano, S., \&Zortéa, M. 2007. Os Mamíferos Ameaçados de Extinção no Estado do Espírito Santo. In: M. Passamani, \& S. L. Mendes (Org.), Espécies da fauna ameaçadas de extinção no estado do Espírito Santo. pp. 29-45. Vitória: Instituto de Pesquisas da Mata Atlântica.

Colwell, R. K., Chao, A., Gotelli, N. J., Lin, S-Y, Mao, C. X., Chazdon, R. L., \& Longino, J. T. 2012. Models and estimators linking individual-based and sample-based rarefaction, extrapolation and comparison of assemblages. Journal of Plant Ecology, 5(1), 3-21. DOI: 10.1093/jpe/rtr044.

Cove, M. V., Spinola, R. M., Jackson, V. L., \& Saenz, J. 2014. Camera trapping ocelots: An evaluation of felid attractants. Hystrix 25(2), 1-4. DOI: 10.4404/hystrix-25.2-9945

Delciellos, A. C., Novaes, R. L. M., Loguercio, M. F. de C., Geise, L., Santori, R. T., Souza, R. de F, Papi, B. S., Raíces, D., Vieira, N. R., Felix, S., Detogne, N., da Silva, C. C. S., Bergallo, H. de G., \& Rocha-Barbosa, O. 2012. Mammals of Serra da Bocaina National Park, state of Rio de Janeiro, southeastern Brazil. Check List, 8(4),675-692. DOI: 10.15560/8.4.675.

Dray, S., \& Dufour, A. B. 2007. The ade4 Package: Implementing the Duality Diagram for Ecologists. Journal of Statistical Software, 22(4),1-20. DOI: 10.18637/jss.v022.i04.

Ehrlén, J., \& Morris, W. F. 2015. Predicting changes in the distribution and abundance of species under environmental change. Ecology Letters, 18(3), 303-314. DOI: 10.1111/ele.12410. 
Ervin, J. 2003. Rapid assessment of protected area management effectiveness in four countries. BioScience, 53(9), 833-841. DOI: 1/0006-3568(2003)053[0833:RAOPAM]2.0.CO;2.

Fernández, N. 2013. Earth observation for species diversity assessment and monitoring. In: D. Alcaraz-Segura, C. Bella, \& J. Straschnoy (Eds.), Earth observation of ecosystem services. pp. 151-178. Boca Raton: CRC Press.

Ferreguetti, Á. C., Rocha, M. F., \& Martins, R. L. 2014. Non-volant mammals from Domingos Martins municipality, state of Espírito Santo, southeastern Brazil. Check List, 10(4),829-834. DOI: 10.15560/10.4.829.

Flesher, K. M., \& Gatti, A. 2010. Tapirus terrestris in Espírito Santo, Brazil. Tapir Conservation, 19(1), 16-23.

Galetti, M., Giacomini, H. C., Bueno, R. S., Bernardo, C. S. S., Marques, R. M., Bovendorp, R. S., Steffler, C. E., Rubim, P., Gobbo, S. K., Donatti, C. I., Begotti, R. A., Meirelles, F., Nobre, R. D. A., Chiarello, A. G., \& Peres, C. A. 2009. Priority areas for the conservation of Atlantic forest large mammals. Biological Conservation, 142(6), 1229-1241. DOI: 10.1016/j.biocon.2009.01.023.

Gatti, A., Segatto, B., Carnelli, C. C., \& Moreira, D. de O. 2014. Mamíferos de médio e grande porte da Reserva Biológica Augusto Ruschi, Espírito Santo. Natureza Online, 12(2), 61-68.

Gatti, A., Ferreira, P. M., da Cunha, C. J., Seibert, J. B., \& Moreira, D. O. O. 2017. Medium and largebodied mammals of the Private Reserve of Natural Heritage Recanto das Antas, in Espírito Santo, Brazil. Oecologia Australis, 21(2), 171 181. DOI: 10.4257/oeco.2017.2102.07\}.

Gonçalves, M. R. 1997. Plano de Manejo da REBIO - Augusto Ruschi. Instituto Brasileiro dos Recursos Naturais Renováveis (IBAMA). Brasília. Available at http://www.icmbio.gov.br/portal/ images / stories /imgs-unidades-coservacao/ rebio_augusto-ruschi.pdf.

Guerra, E. B., \& Leite, Y. L. R. 2017. Non-volant mammals of the Mestre Álvaro Environmental Protection Area, state of Espírito Santo, southeastern Brazil. Check List, 13(6), 935-943. DOI:10.15560/13.6.935.

Huete, A., Didan, K., Miura, T., Rodriguez, E., Gao, X., \& Ferreira, L. 2002. Overview of the radiometric and biophysical performance of the MODIS vegetation indices. Remote Sensing of
Enviroment, 83, 195-213. DOI: 10.1016/S00344257(02)00096-2.

Instituto Chico Mendes de Conservação da Biodiversidade - ICMBio (Ministério do Meio Ambiente - MMA). 2016. Brazil Red Book of Threatened Species of Fauna. Brasília: Instituto Chico Mendes de Conservação da Biodiversidade: p. 76.

International Union for Conservation of Nature and Natural Resources - IUCN. 2018. The IUCN Red List of Threatened Species. Version 2018-1. Available at http://www.iucnredlist.org.

Lacerda, A. C. R., Tomas, W. M., \& Marinho-Filho, J. 2009. Domestic dogs as an edge effect in the Brasília National Park; Brazil: interactions with native mammals. Animal Conservation, 12(5), 477-487. DOI: $10.1111 /$ j.14691795.2009.00277.x.

Legendre, P., \& Legendre, L. 1998. Numerical ecology. Developments in environmental modelling. Amsterdam: Elsevier: p. 969.

Lessa, I., Guimarães, T. C. S., Bergallo, H. G., Cunha, A., \& Vieira, E. M. 2016. Domestic dogs in protected areas: a threat to Brazilian mammals? Natureza \& Conservação, 14(2), 46-56. DOI: 10.1016/j.ncon.2016.05.001.

Lund, U., \& Agostinelli, C. 2012. CircStats - Circular Statistics, from "Topics in circular Statistics". R package version 0.2-4. Available at https:// CRAN.R-project.org $/$ package $=$ CircStats.

Magurran, A. E. 1988. Ecological diversity and its measurement. Dordrecht: Springer Netherlands.

Mendes, S. L., \& Padovan, M. D. P. 2000. A Estação Biológica de Santa Lúcia, Espírito Santo. Boletim do Museu de Biologia Prof. Mello-Leitão, 11(12), 7-34.

Moreira, D. de O., Coutinho, B. R., \& Mendes, S. L. 2008. O status do conhecimento sobre a fauna de mamíferos do Espírito Santo baseado em registros de museus e literatura científica. Biota Neotropica, 8(2), 163-173.

Myers, N., Mittermeier, R. A., Mittermeier, C. G., Fonseca, G. A. B., \& Kent, J. 2000. Biodiversity hotspots for conservation priorities. Nature, 403(6772), 853-858. DOI: 10.1038/35002501.

Oliveira, U., Soares-Filho, B. S., Paglia, A. P., Brescovit, A. D., De Carvalho, C. J. B., Silva, D. P., Rezende, D. T., Leite, F. S. F., Batista, J. A. N., Barbosa, J. P. P. P., Stehmann, J. R., Ascher, J. S., Vasconcelos, M. F., Marco, P., Löwenberg-Neto, 
P., Ferro, V. G., \& Santos, A. J. 2017. Biodiversity conservation gaps in the Brazilian protected areas. Scientific Reports, 7(1), 1-9. DOI: 10.1038/ s41598-017-08707-2.

Paglia, A. P., da Fonseca, G. A. B., Rylands, A. B., Herrmann, G., Aguiar, L. M. S., Chiarello, A. G., Leite, Y. L. R., Costa, L. P., Siciliano, S., Kierulff, M. C. M., Mendes, S. L., Tavares, V. C., Mittermeier, R. A., \& Patton, J. L. 2012. Lista anotada dos mamíferos do Brasil, 2a Edição. Occasional Papers in Conservation Biology, 6(6), 1-76.

Palomares, F., Fernández, N., Roques, S., Chávez, C., Silveira, L., Keller, C., \& Adrados, B. 2016. Fine-scale habitat segregation between two ecologically similar top predators. PLoS ONE, 11(5), 1-16. DOI: 10.1371/journal.pone.0155626.

Passamani, M., Mendes, S. L., \& Chiarello, A. G. 2000. Non-volant mammals of the Estação Biológica de Santa Lúcia and adjacent areas of Santa Teresa, Espírito Santo, Brazil. Boletim do Museu de Biologia Prof. Mello-Leitão, 11(12), 201-214.

Patton, J. L., Pardiñas, U. F. J., \& D’Elía, G. 2015. Mammals of South America: rodents. Chicago and London: The University of Chicago Press: $p$. 1336.

Pimm, S. L., \& Jenkins, C. N. 2010. Extinctions and the practice of preventing them. In: Sodhi, N. S., Ehrlich, P. R. (Eds.), Conservation biology for all. pp. 181-196. New York: Oxford University Press. DOI: 10.1093/ acprof:oso/9780199554232.003.0011.

Pinto, L. P. S., Costa, C. M. R., Strier, K. B., \& Fonseca, G. A. B. 1993. Habitat, density and group size of primates in a Brazilian tropical forest. Folia Primatologia, 61, 135-143. DOI: 10.1159/000156740.

R Core Team. 2016. R: A language and environment for statistical computing. $\mathrm{R}$ Foundation for Statistical Computing, Vienna, Austria. Available at https://www.R-project.org/.

Rao, M., Johnson, A., \& Bynum, N. 2007. Assessing threats in conservation planning and management: synthesis. Lessons in Conservation, 1, 44-71.

Srbek-Araujo, A. C., \& Chiarello, A. G. 2007. Armadilhas fotográficas na amostragem de mamíferos: considerações metodológias e comparação de equipamentos. Revista Brasileira de Zoologia, 24(3), 647-656. DOI:

\subsection{0/S0101-81752007000300016.}

Srbek-Araujo, A., \& Chiarello, A. G. 2008. Domestic dogs in Atlantic forest preserves of south-eastern Brazil: a camera-trapping study on patterns of entrance and site occupancy rates. Brazilian Journal of Biology, 68(4), 771-779. DOI: 10.1590/ S1519-69842008000400011.

Tonini, J. F. R., Carão, L. M., Pinto, I. S., Gasparini, J. L., Leite, Y. L. R., \& Costa, L. P. 2010. Non-volant tetrapods from Reserva Biológica de Duas Bocas, State of Espírito Santo, Southeastern Brazil. Biota Neotropica, 10(3), 339-351. DOI: 10.1590/ S1676-06032010000300032.

Tuck, S. L., Phillips, H. R. P., Hintzen, R. E., Scharlemann, J. P. W., Purvis, A., \& Hudson, L. N. 2014. MODISTools - downloading and processing MODIS remotely sensed data in $\mathrm{R}$. Ecology and Evolution, 4(24), 4658-4668. DOI: 10.1002/ece3.1273.

Wilson, D. E., \& Reeder, D. M. 2005. Mammal species of the world: a taxonomic and geographic reference. Baltimore: Johns Hopkins University Press: p. 1945.
Submitted: 19 February 2018 Accepted: 17 July 2018

Published online: 16 November 2018 Associate Editor: Rita Bianchi

Oecol.Aust.23(1): 66-77, 2019 